\title{
The Structure and Development of the Ovule of Myrica Gale.
}

\author{
BY \\ EDITH MAY KERSHAW, M.Sc., \\ Graduate Scholar in Botany in the University of Manchester. \\ With Plate XXIV, and two Figures in the Text.
}

T view of the important peculiarities noted in the structure and develop1 ment of the ovule of Casuarina and the Amentiferae, and of our rapidly extending knowledge of the seeds of the older Gymnosperms, it seems important that the ovules of allied orders such as the Myricaceae should be carefully examined, as so far only Myrica Lobbii had been examined in detail by Treub.

When Treub ${ }^{1}$ published in $189 \mathrm{I}$ the account of his very thorough investigation of the Casuarinaceae which had led to interesting discoveries, he suggested that this group should be placed in a separate subdivision of Angiosperms. In summing up his conclusion (p. 209), he says, 'Les Casuarinées occupent très probablement par les phénomènes qui se passent dans leur nucelle avant la fécondation une place tout à fait exceptionnelle parmi les Angiospermes.' These exceptional phenomena in the nucellus are-the considerable development of sporogenous tissue, composed of hundreds of cells-the great number of macrospores which develop, sometimes twenty or more,- the entrance of the pollen-tube into the nucellus by the chalaza. 'Ce sont là autant de points cardinaux qui distinguent les Casuarina des autres Angiospermes' (p. 2I5).

From a comparative study of the Amentiferae, Juglandaceae, and Myricaceae which were considered as groups closely allied to the Casuarinaceae, Treub concluded that Casuarinaceae were the only group which showed these exceptional characters, and so he suggested a division of the Angiosperms into two classes:-

Chalazogames-containing the family Casuarinaceae, and Porogamescontaining the rest of the Angiosperms, the names being derived from the - mode of entrance of the pollen-tube into the nucellus.

1 Treab : Ann, da Jard. Bot. de Baitenzorg, vol. x, pp. 145-231.

[Annale of Botany, Vol. XXIII, No. XCI. July, Igog.] 
Miss Benson's ${ }^{1}$ work on the Amentiferae showed that this classification could not possibly be adopted. Treub was evidently misled by Hofmeister's account in $185^{8}$ of the embryology of the Amentiferae, for Miss Benson very clearly shows that Betula, Alnus, Corylus, and Carpinus are also Chalazogams. In many other characters also the Amentiferae very closely resemble Casuarina.

There is a considerable amount of sporogenous tissue, which although differing in detail from that of Casuarina, is thought by Miss Benson to constitute an important point of resemblance; the pollen-tubes are of the branching type, and in many genera enter the nucellus through the chalaza. Such characters as the large amount of sporogenous tissue in the ovule and the great number of macrospores which develop, may be regarded as primitive, and have been considered to support the position assigned to the Amentiferae and Casuarinaceae by Engler in his scheme of classification of the Angiosperms.

The investigations of Nawaschin ${ }^{2}$ on Fuglans regia, and those of Karsten ${ }^{3}$ which extended to other members of the Juglandaceae, show that chalazogamy prevails also in this family.

It is interesting to note Nawaschin's views on chalazogamy. $\mathrm{He}$ states : ' die Chalazogamie stellt eines von den Uebergangsstadien dar bei der Umwandlung des intercellularen Wachsthums des Pollenschlauches im gymnospermen Fruchtknoten zum freien Wachsthum durch die Fruchtknotenhöhle der Angiospermen.'

A more detailed account of the structure and development of the ovule of $\mathcal{F u g l a n s}$ regia was given by Nicoloff ${ }^{4}$ in 1904 , details of which will be referred to later.

As regards the Myricaceae, Treub ${ }^{5}$ had already in his paper on Casuarina shown that in Myrica Lobbii the course of the pollen-tube was not chalazogamous, but that development and fertilization were of the normal Angiospermous type.

As this was based on one species only, it was suggested that an investigation of the ovules of other species might prove interesting as a further comparison.

For this purpose Myrica Gale, which grows fairly abundantly round some of the Cheshire meres,-particularly Hatchmere in Delamere Forestwas chosen.

I found in this British species, just as Treub found in Myrica Lobbii, that

1 Benson: Trans. Linnean Soc., London, vol. iii, part 10, 1894.

2 Nawaschin : Ein netes Beispiel der Chalazogamie. Bot. Centr., 1895, 63.

- Karsten: Ueber die Entwickelung der weiblichen Blüthen bei einigen Juglandaceen. Flora, 9o. Band, rgor.

- Nicoloff : Sur le type floral et le développement du frait des Juglandées. Journal de Botanique, t. xxviii-xxix.

- Treub : loc. cit. 
the development and fertilization of the ovule is quite of the normal Angiosperm type. There is only a single embryo-sac mother-cell which divides to form several superposed cells, the lowest of which absorbs the rest and forms the embryo-sac. The nucleus of the embryo-sac divides, eight nuclei eventually being formed as in the typical Angiosperm. The pollen-tube bearing two male cells enters the micropyle (PI. XXIV, Fig. I), penetrates the apex of the nucellus and pushes its way into the embryo-sac, at the top of which is the sexual apparatus, consisting of the egg-cell and two synergids. Fusion takes place resulting in the formation of a normal dicotyledonous embryo and a development of endosperm.

In the development of the ovule then, Myrica Gale does not show any of those characteristics, e. g. great development of sporogenous tissue, numerous macrospores, chalazogamy, \&c., which are found in nearly related families, and which are generally regarded as primitive characters. Certain anatomical features of the ovule, however, seem to be of sufficient interest to be recorded in some detail.

As is well known, the flowers which are borne in axillary catkins are either monoecious or dioecious. The female flower is devoid of perianth. The ovary, sessile in the axil of a bract, is furnished with two sterile scales, which become fused with the ovary wall. The ovary contains a single ovule which is orthotropous and quite sessile (Fig. 2). The nucellus, which is long and oval in shape (n), tapering to form a distinct stalk at the base, is surrounded by a single integument (i). A peculiar feature is that the nucellus stands up quite freely within this integument, from the stalk-like portion at the base to the apex.

Another very interesting feature is found in the vascular supply to the ovule (Text-fig. I).

A transverse section below the base of the ovule shows a ring of vascular bundles, usually eight or nine in number, with phloem on the outer side (Text-fig. I, I). As the ring of bundles traverses the stalk of the ovule, four small branches are given off and run outwards-two to supply the two bracts which are fused to the ovary (Text-fig. I, $2 a$ and Fig. $2 b$ ), and the remaining two to supply the ovary wall (Text-fig. I, $2 b$ ). These four vascular bundles traverse their courses without branching, the ones to the bracts running up the centre of the bract to the tip, those to the ovary wall running up into the stigmas (Fig. 2, st.). Just after these four bundles have branched off the ring of bundles in the stalk of the ovule begin to curve inwards (Text-fig. I, 3 and Fig. 2 m.b.), and gradually unite by fusing together, so that a transverse section immediately at the base of the ovule shows a solid strand of wood surrounded by a ring of phloem (Text-fig. I, 4). When this solid strand reaches the base of the nucellus it expands to form a shallow cup-like mass of tracheids. Text-fig. I, 5 shows the centre of the cup, and Text-fig. I, 6, 

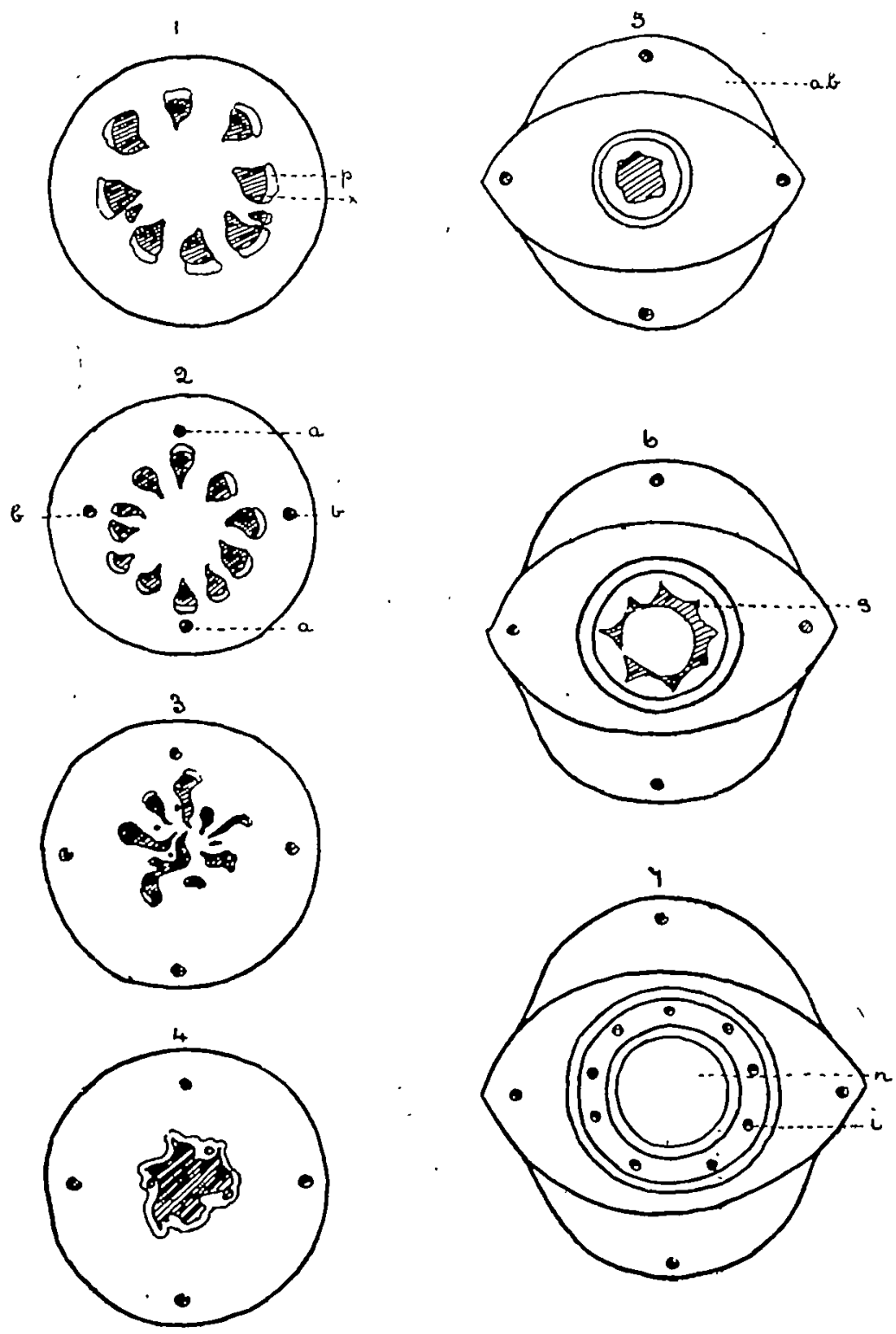

Text-FIG. I. Diagram of a series of transverse sections from base of ovary to npper part. I, 2, 3, 4, through base of ovary; 5 and 6 , through stalk of ovale; 7 , through upper part of ovale. $a$ = vascular bundle supplying bract; $b$ a vascular bundle supplying ovary wall; $i$ = integumentary bundle; $n$ m nucellus; $s=$ vascular strand about to enter integument; $a . b$. = adherent bract; $p=$ phloem; $x=$ xylem. 
a section a little higher in the series shows the edges. This is shown in longitudinal section in Fig. 2.

Generally in the ovules of recent plants, the vascular supply terminates here, i. e. in a flat plate of tracheids at the base of the nucellus, but in Myrica Gale, the edges of this cup of tracheids run out into eight or nine slender vascular strands, each composed of a few tracheids and a small quantity of phloem, which traverse the single 'integument (Textfig. I, $7 i$, and Fig. 2 i.b.).

A tangential section of the integument showing these vascular strands is represented in Fig. 3. The strands pass up the integument without branching, getting smaller as they get higher, until, almost at the apex of the ovule, the strand which has diminished to a single tracheid dies out (Fig. 2 i.b.).

In a transverse section of the ovule, therefore, one finds a ring of eight to nine small vascular bundles as seen in Text-fig. I, $7 i$.

Running up the centre of the nucellus from its base to the base of the embryo-sac is a strand of tissue, consisting of parenchymatous cells considerably elongated in the vertical direction (Fig. 2 c.s.). This strand of tissue probably facilitates the conduction of food material to the embryo, since it connects the cells at the base of the nucellus which have very dense contents, with the embryo-sac.

These characters, i. e. the free nucellus and the vascular supply running up into the integument are remarkable-occurring as they do in a family of recent plants, and may be regarded as being of phylogenetic interest.

In living Angiosperms the nucellus and integument are generally fused together almost to the apex, and the integument is devoid of vascular tissue.

It will be remembered, however, that a free nucellus and vascular nteguments were prevalent in many of the fossil plants.

The ovules of some of the Pteridosperms and many of the fossil Gymnosperms have been described as having a free nucellus. Almost all the fossil seeds described by Brongniart' in his 'Recherches sur les graines fossiles silicifiées' are represented as having a nucellus quite free from the surrounding integument.

Trigonocarpus, probably the seed of Medullosa, recently described by Scott and Maslen, ${ }^{2}$ and the ovule of Myrica Gale show a great similarity of structure (Text-fig. II). Both of them possess a single integument, and in each case the nucellus stands up freely within it.

This character of a free nucellus in these older fossil seeds may indicate that the integument had not as yet become an integral part of the seed.

1 Brongniart ('81): Recherches sur les graines fossiles silicifíes. Paris.

' Scott and Maslen: The Stractare of the Palaeozoic Seeds, Trigonacarpus Parkinsoni, Brongalart, and Trig. Oliveri, sp. now. Ann. of Bot., vol. xxi, Jan., 1907. 
A free nucellus, therefore, may be regarded as a primitive character which has been lost in the greater number of Angiosperms, where the integument and nucellus are fused together almost to the apex of the ovule.

Oliver, ${ }^{1}$ in his paper on 'The Ovules of the Older Gymnosperms', suggests that in the seeds of Cycads, \&c., where the nucellus is not free to the base, 'the whole body of the ovule, below the level at which the

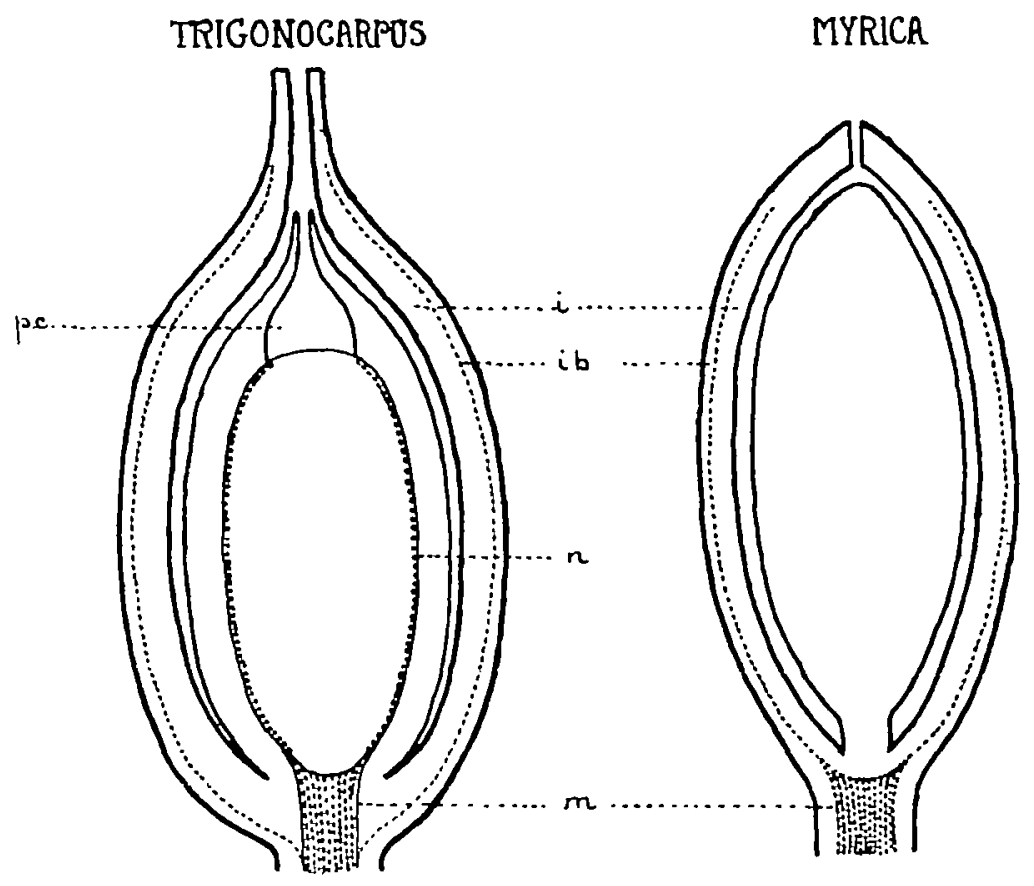

Text-FIG. II. Diagrammatic representation of median sections through ovules of Trigonocarpus and Myrica Gale to show similar constraction of the seed and vascular supply to the integument. $i$ integament; $i . b .=$ integumentary vascular bundle; $m=$ main supply bundle; $n=$ nucellar vascular supply; p.c. = pollen chamber.

nucellus becomes free, is phylogenetically younger than its apical parts,' and 'between the original ovule and its insertion a new region has been intercalated'.

Myrica, therefore, seems to have retained an ancestral character or to have reverted to the former state such as obtained in the fossil seeds with a free nucellus, and there is no indication of an intercalated portion such as has been suggested for those seeds where the nucellus and surrounding integument are fused together.

Whether this character is really the ancestral one retained or a secondary character almost identical with the ancestral one, can hardly be

1 Oliver ('03): The Ovales of the older Gymnosperms Ann. of Bot., vol. xvii. 
determined; but it is interesting to remember that it occurs in a group of recent plants which is regarded by many botanists as primitive.

Turning now to the other character of the ovule of Myrica Gale which has been specially noted-the continuation of the vascular supply into the integument-it does not seem very easy to explain the presence of this integumentary vascular system by any special requirements of the integument, as it is neither of great thickness, nor does it become succulent when ripe. Probably it is correlated with the complete separation of the nucellus from the integument, which renders it impossible for the integument to receive its nutriment through the nucellus, as is possible in most seeds where only the apical portion of the nucellus is free.

Comparing the ovule of Myrica Gale with the seed of Trigonocarpus in respect to the vascular system, we find again a certain resemblance (Text-fig. II). In Trigonocarpus the main supply bundle to the ovule gave off at a short distance below the chalaza a number of branch bundles, usually six to nine, which, bending outwards, traversed the sarcotesta of the integument. In Myrica we find a similar arrangement of integumentary bundles given off from the main supply bundle.

The existence of such an integumentary vascular supply in fossil secds such as Trigonocarpus, where we have an integument free from the nucellus, is interesting in comparison, and supports the view of a correlation of these two characters.

In Trigonocarpus the main supply bundle, after giving off the integumental bundles, continued unbranched through the stalk of the seed until it reached the nucellus. There it expanded to form an apparently continuous mantle of tracheids investing the macrospore and terminating as anastomosing strands just below the pollen-chamber.

In Myrica, of course, there is no necessity for such a system of nucellar tracheids as was required by an ovule with a large pollenchamber, filled at the time of fertilization with water; but there is, as described above, the distinct strand of elongated cells running up the centre of the nucellus which evidently serves the purpose of nutrition of the embryo-sac (Fig. 2, c.s.).

This central strand of elongated parenchymatous cells in the nucellus of Myrica Gale may possibly represent the remains of an ancient nucellar vascular system, or it may be a new structure developed to facilitate the conduction of nutritive material to the embryo-sac. When one remembers the tracheids found by Miss Benson ${ }^{1}$ in the nucellus of Castanea, and by Treub' ${ }^{2}$ in that of Casuarina, regarded by Miss Benson as 'a vestige of some long lost structure', one is inclined to regard this

1 Benson: loc. cit.

Treob : loc. cit.

C c 
central strand in the nucellus of Myrica Gale, which is a comparable structure to the tracheids in Castanea as also 'a vestige of some long lost structure'.

It is interesting to find that in two families generally regarded as closely related to the Myricaceae, the structure of the ovule resembles very closely that of Myrica Gale.

Nicoloff ${ }^{1}$ in his treatise on the Juglandaceae produces several figures of the ovule of Fuglans regia which show that very similar features are found to those which have been described for Myrica Gale. In a longitudinal section of the ovule which is orthotropous, he figures the nucellus as being quite free to the base from the integument (Nicoloff, l.c., Fig. 18). In a transverse section he represents the integument as having a ring of vascular bundles, ten in number (Nicoloff, l.c., Fig. 3I). Although these characters are described by Nicoloff he does not suggest in any way their probable phylogenetic value.

In the recently investigated allied order of Julianiaceae, ${ }^{2}$ the ovule of Fuliania is described as having an integument containing a branching system of vascular bundles. The nucellus is figured as being fused to the single integument however. This may be accounted for by the fact that the ovule is hemi-anatropous, not orthotropous as in the cases described where the nucellus is free.

The absence of these two apparently primitive characters of the ovule in the allied groups of Amentifcrae and Casuarinaceae may be connected with the change from the orthotropous to the anatropous type of ovule.

A comparison of the structure of the ovule in the families Juglandaceae, Julianiaceae, and Myricaceae may throw some light on the position of these families in the Natural Classification, a point which has given rise to some discussion.

Hallier ${ }^{\circledR}$ regards the Amentiferae including Myricaceae as a degenerate group derived probably from the Terebinthaceae in which are included Anacardiaceae, Juglandaceae, and Julianiaceae.

Hemsley, ${ }^{4}$ on the other hand, regards the groups Juglandaceae, Julianiaceae, and Amentiferae as very closely allied, the Julianiaceae probably occupying a position immediately between Juglandaceae and Amentiferae.

The evidence derived from the structure of the ovule undoubtedly

1 Nicoloff: Sur le type floral et le développement du frait des Jaglandées. Journal de Botanique, t. rrviii-xxix.

1W. Botting Hemsley: On the Julianiaceae. A New Natural Order of Plants. Phil. Trans. Roy. Soc., rol. crcix, 1908 .

- Hallier: 'Uber Fuliania, eine Terebinthaceen-Gattung mit Cupula, und die wahren Stammeltern der Kätzchenblütler: Presden, Igo8. 
supports the latter view. The ovules of the orders Julianiaceae, Myricaceae, and Juglandaceae-especially of the two latter-are very similar, retaining, if the foregoing is correct, ancestral characters. The Julianiaceae show one step in advance of the other two orders in the change from the orthotropous to hemi-anatropous type of ovule, thus obliterating one of the 'ancestral characters' described in the other two orders. The Amentiferae show a further advance in this respect, the ovule being truly anatropous. As a result of this change in the position of the ovule, probably more pressure came to bear on the parts of the ovule than they would be subjected to in the orthotropous condition, the integument and nucellus therefore came into closer contact, and since the integument was not large, and did not become succulent, there was no longer any need for an integumental vascular system.

Although the Amentiferae have advanced further than the Myricaceae and Juglandaceae in respect to the structure of the ovule, they show a more primitive state of affairs than do the latter in the development of the ovule, examples of chalazogamy, numerous macrospores, \&c., being found as described above.

Thus in the structure and development of the ovule these closely allied orders show, as is shown in the evolution of all groups of plants, an unequal development of parts. The Amentiferae which have advanced farthest in the specialization of the ovule, losing such ancestral characters as the free nucellus and integumentary vascular supply, still retain a primitive mode of development of the embryo-sac; while others such as the Myricaceae which show these primitive characters in the structure of the ovule, have advanced to the normal Angiospermous type of development of the embryo-sac.

The evidence derived from the structure and development of the ovule in the series of plants including Juglandaceae, Myricaceae, Amentiferae, Casuarinaceae, and Julianiaceae, seems to me to support the view that they are a primitive group of Angiosperms, and should therefore retain the position assigned to them by Engler in his scheme of classification.

The alternative suggestion made by Arber and Parkin ${ }^{1}$ and by Hallier ${ }^{2}$ that the Amentiferae are degenerate orders descended from ancestors of the Ranales type is not supported by the facts obtained in my investigation of Myrica Gale, for the development of vascular supply in the integument can hardly be regarded as a step in the degeneration of an ovule, nor is the development of a large amount of sporogenous tissue in the ovule observed by Miss Benson in some of the Amentiferae in accordance with our views of degeneration.

1 Arber and Parkin ('07): On the Origin of Angiosperms. Linn. Soc. Joumal of Botany, vol. xxrviii.

- Hallier ('08): Uber Fuliania, eine Terebinthaceen-Gattung mit Cupula. Dresden, Igo8. 


\section{Kershaw. - Structure of the Ozule of Myrica Gale.}

I take this opportunity of thanking Professor Weiss for the help he has given me in this work, and the many suggestions he has made from time to time; also my thanks are due to Miss K. H. Coward, M.Sc., for preparing many of the necessary microtome sections.

UNIVERSITY OP MANCHESTER, March, igog.

\section{EXPLANATION OF PLATE XXIV.}

Illustrating Miss Kershaw's paper on Myrica Gale.

Fig. I. Long. sect. through apex of ovale of Myrica Gale showing pollen-tube with two male cells entering through the micropyle.

Fig. 2. Long. sect. through ovary at end of July. n. nucellus; s. stalk of nucellus; $i$ integument; $b$. vascular bundle of bract; st. vascular bundles of ovary wall, terminating in stigma; m.b. main supply bundle to ovule; i.b. vascular bundle supplying integument; e.s. central strand of elongated parenchymatous cells ranning from base of nucellas to embryo-sac; e. embryo-sac; a.b. adberent bract.

Fig. 3. Tangential section through integament of ovule showing vascular strands. 
इ্

(1)

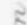

3 . 30 .

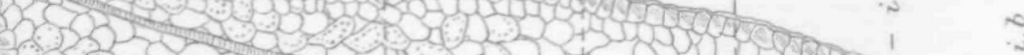

(2)

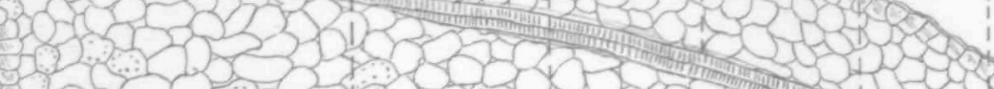

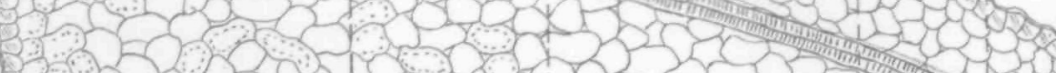
3.2012

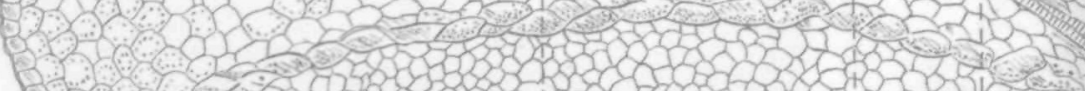

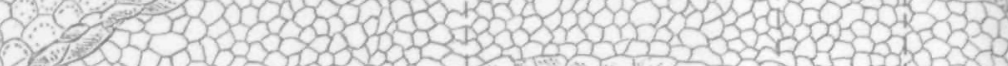

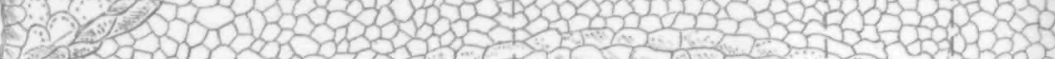

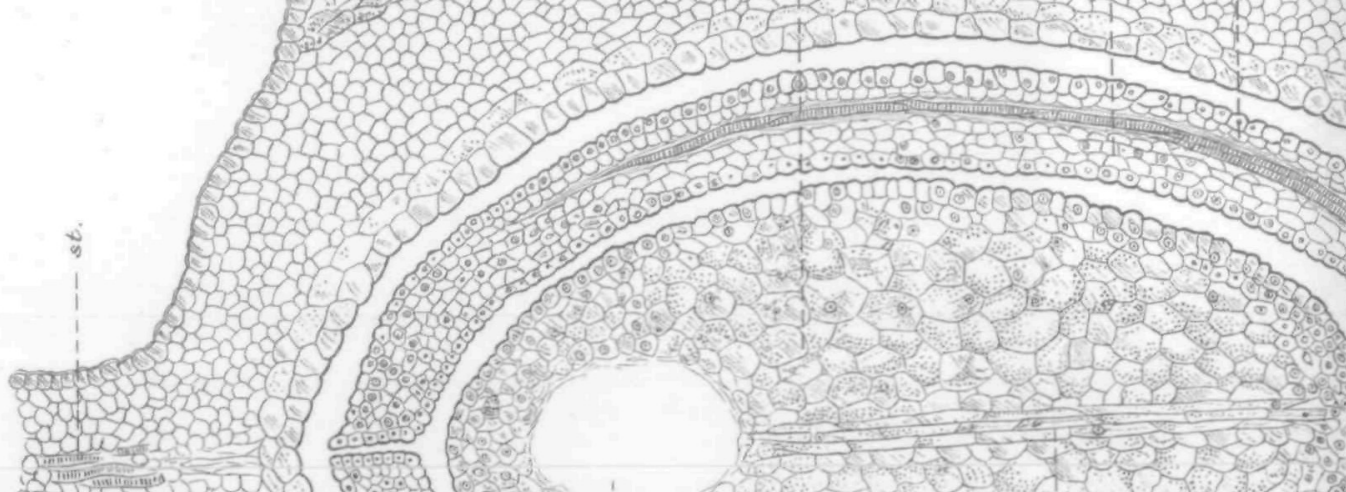

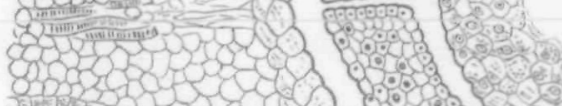

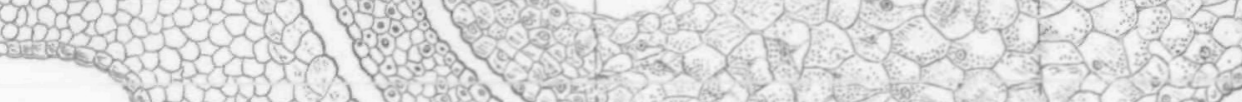

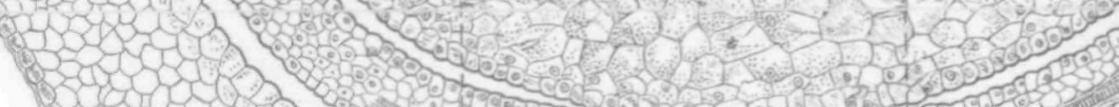

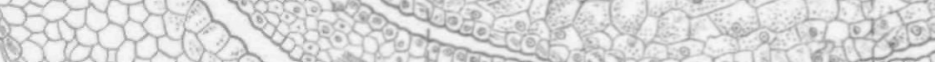

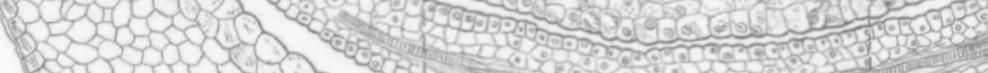

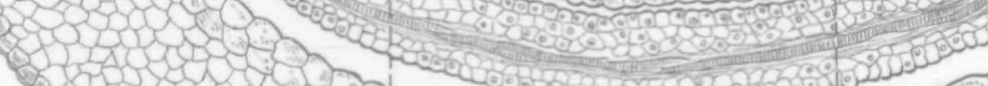

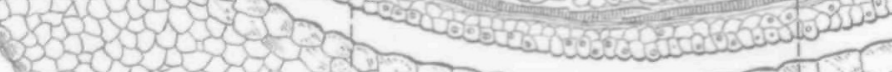

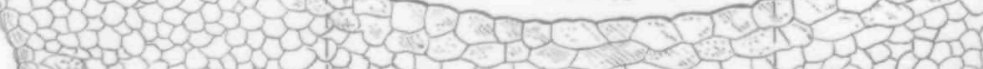

N

हे
8
0
0
5
कै
ई
5

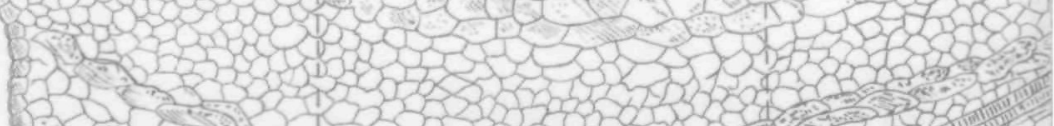
1.2 र

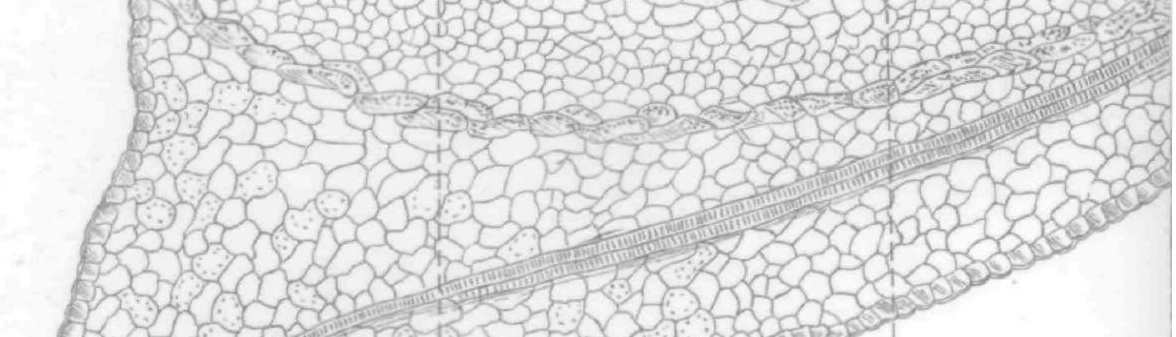

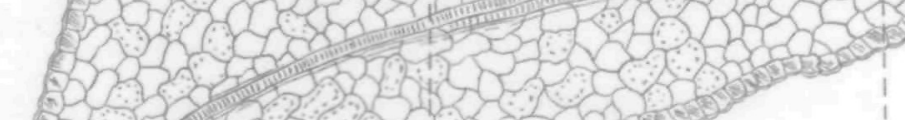

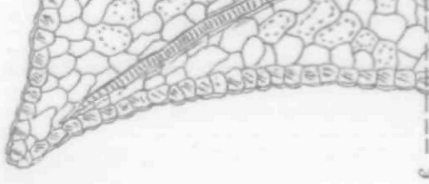




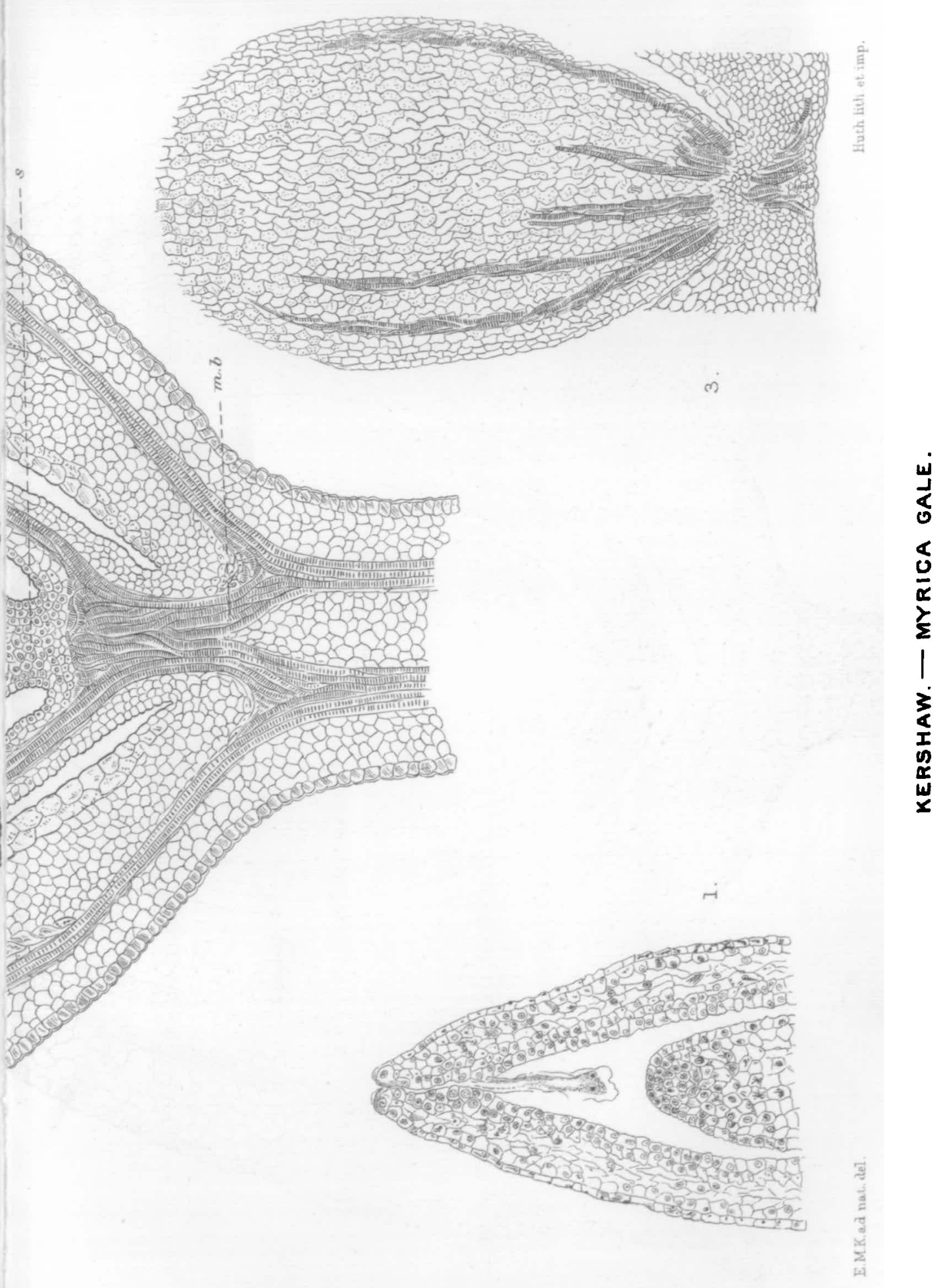


